Bul. Agrohorti 4 (1) : 9 - 19 (2016)

\title{
Pengelolaan Aspek Produksi dan Pasca Panen Sayuran Daun Secara Aeroponik dan Hidroponik : Studi Kasus Lembang, Bandung
}

\section{Production and Post Harvest Management of Leafy Vegetables in Aeroponic and Hydroponic System : Lembang, Bandung}

\section{Benny Rahardian Prawoto dan Juang Gema Kartika*}

Departemen Agronomi dan Hortikultura, Fakultas Pertanian, Institut Pertanian Bogor (Bogor Agricultural University), J1. Meranti, Kampus IPB Darmaga, Bogor 16680, Indonesia Telp.\&Faks. 62-251-8629353 e-mail agrohort.ipb.ac.id

*Penulis untuk korespondensi: ika_juang@yahoo.com

Disetujui 18 Januari 2016/Published online 25 Januari 2016

\begin{abstract}
Vegetables are needed by human being as their consumption to fulfill their daily nutrition, that's why the opportunity of vegetables production is widely opened to be developed. This opportunity drives people to use the suitable technique to gain optimum production as well as the quality, quantity and continuity, such as using aeroponic and hydroponic system. The research was implemented in Field Cikahuripan 1, Lembang, Bandung. The purposes of the study were to get applied knowledge about production of aeroponic and hydroponic lettuce (green curly, lollorossa and romaine). Aeroponic system produced lettuce crop better than those of hydroponic. The post harvest observation of aeroponic and hydroponic lettuce didn't show significant diference. The bussines analysis of lettuce production showed that aeroponic lettuce was more profitable than hydroponic, although it needed larger amount of capital for the initial investement.
\end{abstract}

Keywords: aeroponic, hydroponic, lettuce, organic

\begin{abstract}
ABSTRAK
Sayuran dikonsumsi oleh manusia untuk memenuhi sebagian asupan nutrisi sehari-hari, oleh sebab itu masih terbuka peluang dalam mengembangkan produksi sayuran skala luas. Kesempatan ini mendorong orang untuk menggunakan teknik budi daya yang mampu menghasilkan produk yang berkualitas, kuantitas, dan kontinuitas secara optimal salah satunya dengan menggunakan sistem aeroponik dan hidroponik Penelitian ini dilaksanakan di Kebun Cikahuripan 1, Lembang, Bandung. Tujuan penelitian ini untuk mempelajari produksi sayuran (Selada keriting, Lollorossa dan Romaine) secara aeroponik dan hidroponik. Sistem aeroponik menghasilkan selada yang lebih baik dibandingkan menggunakan sistem hidroponik. Pengamatan pasca panen tidak berbeda nyata pada selada aeroponik dan hidroponik. Analisis keuntungan produksi menunjukkan selada hasil sistem aeroponik lebih menguntungkan dibandingkan selada pada sistem hidroponik walaupun membutuhkan modal awal yang lebih besar.
\end{abstract}

Kata kunci: aeroponik, hidroponik, selada, organik 


\section{PENDAHULUAN}

Pangan merupakan sumber energi bagi manusia, dan makanan tersebut secara langsung atau tidak langsung berasal dari tanaman yang sebagian besar termasuk dalam kelompok sayuran (Rubatzky et al., 1999). Sayuran mutlak diperlukan dalam konsumsi masyarakat sehari-hari karena kandungan gizinya, terutama vitamin dan mineral yang dapat mendukung kecukupan gizi masyarakat, sehingga peluangnya besar untuk dikembangkan. Peluang ini dapat dilihat dari perkembangan nilai ekspor komoditas sayuran di Indonesia yang terus mengalami peningkatan yang cukup signifikan yaitu senilai US\$ 47000000 pada tahun 2007, menjadi US\$ 52300000 pada tahun 2008 dan mencapai nilai US\$ 74200000 pada tahun 2009 (Kemendag RI, 2011). Peluang ini memacu berbagai pihak untuk menggunakan teknik budi daya yang paling sesuai untuk mencapai produksi yang optimal. Salah satu cara tersebut adalah teknik budi daya sayuran secara hidroponik dan aeroponik.

Hidroponik adalah istilah yang digunakan untuk merujuk pada suatu sistem bercocok tanam dengan media tanpa tanah (Lingga, 1999). Prinsip dasar dari budi daya hidroponik adalah menyediakan suplai nutrisi ke tanaman tanpa menggunakan media tanah. Aeroponik pada dasarnya termasuk ke dalam tipe sistem budi daya hidroponik (Sutiyoso, 2003), namun prinsip kerjanya berbeda. Pada aeroponik, air bernutrisi dikabutkan dan disemprotkan langsung ke akar tanaman. Posisi akarnya menggantung, sehingga tanaman mendapat nutrisi dari air yang disemprotkan tersebut.

Praktik budi daya seperti ini dapat digunakan untuk beberapa jenis tanaman, antara lain stroberi, mentimun jepang, paprika, sishito (cabai Jepang), tomat, dan sayuran daun (Untung, 1999). Jenis sayuran daun yang dapat dibudi dayakan dengan sistem hidroponik atau aeroponik misalnya saja selada keriting, lollorossa, romaine, caisim, kangkung, bayam, bayam merah, kailan dan beberapa jenis sayuran daun yang lain.

Kegiatan bertujuan untuk mendapatkan pengetahuan praktis tentang aspek produksi (kuantitas, kualitas dan kontinuitas) budi daya sayuran daun secara aeroponik dan hidroponik.

\section{BAHAN DAN METODE}

Kegiatan magang dilaksanakan di Kebun Cikahuripan 1, Kampung Pojok, Desa Cikahuripan RT 5 RW 1, Kecamatan Lembang,
Bandung - Jawa Barat, mulai bulan Maret 2011 sampai bulan Juli 2011.

Budi daya, panen, pasca panen dan pemasaran tiga jenis selada yang terdiri atas: selada keriting, lollorossa, dan romaine diamati secara khusus. Proses pengumpulan data dan informasi yang dilakukan berupa pengumpulan data primer dan sekunder. Data primer diperoleh dari hasil pengamatan langsung di lapangan berupa data yang berkaitan dengan aspek budi daya dan juga kegiatan wawancara dan diskusi dengan manajer dan karyawan. Data sekunder didapat dari arsip dan juga studi literatur perusahaan berupa produktivitas, kondisi perusahaan, bangunan tanam, tenaga kerja dan data-data lain yang mendukung.

Pengamatan pada bagian produksi terdiri dari semua kegiatan produksi, mulai dari persiapan bahan tanam, persemaian, penanaman dan perawatan. Komoditas yang menjadi objek pengamatan terdiri dari tiga jenis selada yaitu selada keriting, lollorossa, dan juga romaine secara aeroponik maupun hidroponik. Parameter yang diamati untuk pengamatan persemaian adalah daya berkecambah, sedangkan parameter untuk pengamatan pertumbuhan tanaman adalah tinggi tanaman, lebar daun tanaman, jumlah daun tanaman, panjang akar tanaman dan bobot per tanaman saat panen.

Pengamatan kegiatan panen yang dilakukan oleh perusahaan, pengumpulan data tentang persentase tanaman yang tidak dipanen, dan juga produktivitas. Pengamatan pasca panen meliputi pengamatan presentase rompesan daun, presentase tanaman yang tidak masuk standar kualitas (sortasi), pengamatan pengemasan, dan juga kehilangan hasil. Pengamatan pemasaran yaitu mengamati saluran pemasaran sayuran daun yang diproduksi ke outlet penjualan di sekitar Bandung. Melakukan analisis usaha tani terhadap produksi selada secara aeroponik dan hidroponik.

Data yang diperoleh dan dikumpulkan dari kegiatan magang berupa data primer dan sekunder, diolah dengan menggunakan analisis kuantitatif dan analisis deskriptif. Analisis kuantitatif dilakukan pada data primer dan sekunder yang bersifat kuantitatif dengan menggunakan persentase dan juga uji-t student, sedangkan data yang bersifat kualitatif dianalisis dengan menggunakan analisis deskriptif. 


\section{HASIL DAN PEMBAHASAN}

\section{Kondisi umum}

Kebun terletak di dataran tinggi di daerah Cikahuripan, Lembang, Jawa Barat memiliki curah hujan $3000 \mathrm{~mm}$ per tahun dan memilki suhu udara rata-rata antara $19-23^{\circ} \mathrm{C}$ dan ketinggiannya 1312 hingga $2084 \mathrm{mdpl}$ yang sangat ideal yaitu untuk membudi dayakan sayuran daun seperti selada.

\section{Aspek Produksi}

Persemaian dan Nursery. Media semai menggunakan rockwool sebagai media persemaian. Cara persemaian yang dilakukan adalah adalah dengan cara menyusun benih satu per satu di atas slab rockwool berukuran $24 \mathrm{~cm} \mathrm{x}$ $5 \mathrm{~cm} \times 1.5 \mathrm{~cm}$ dengan menggunakan pinset. Satu slab rockwool terdapat 36 benih sayuran, dengan susunan 3 benih melintang dan 12 benih membujur (3 x 12). Benih-benih yang akan disemai, sebelumnya telah direndam selama beberapa jam di dalam air. Rockwool yang sudah terdapat benih di atas permukaannya kemudian dicelupkan ke dalam air, lalu dimasukkan ke dalam ruang gelap selama 2 hari. Setelah 2 hari, benih yang telah berkecambah dipindahkan ke greenhouse nursery.

Sistem aeroponik terdapat masalah seperti tanaman tidak merata tingginya salah satunya pada tanaman selada kering. Hal ini secara tidak langsung akan menurunkan produktivitas karena hanya sebagian tanaman yang memenuhi kriteria untuk dipanen (Gambar 1a). Selain itu, penggunaan styrofoam bekas akan memicu tumbuhnya ganggang yang membuat tempat menjadi kotor (Gambar 1b).
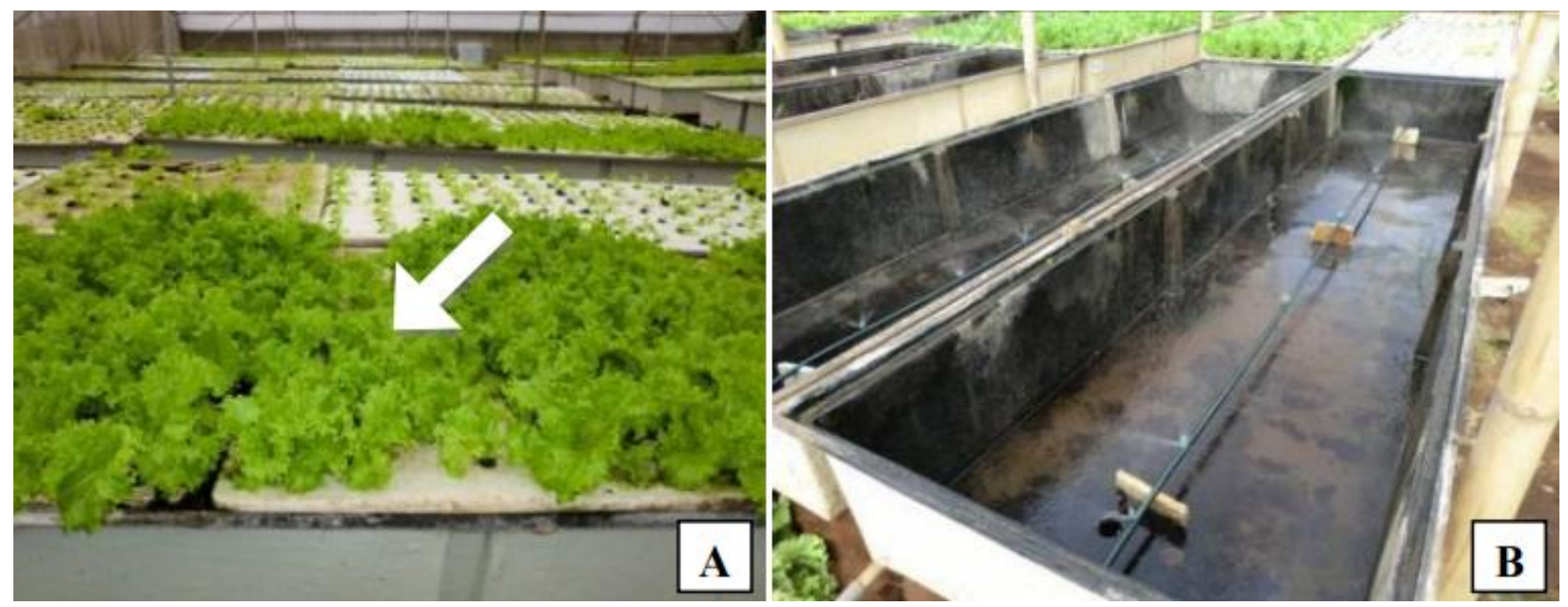

Gambar 1. Masalah pada budidaya aeroponik (A), tinggi tanaman selada keriting yang tidak merata (B) selang yang diganjal styrofoam bekas

Media tanam untuk persemaian berupa rockwool merupakan pilihan yang baik, sebab menurut Resh (2004), rockwool dapat menyediakan oksigen, air, nutrisi dan dapat menunjang akar tanaman. Rockwool memiliki ruang pori sebanyak $95 \%$ dan memiliki kapasitas pegang air sebesar $80 \%$. Keunggulan rockwool tersebut mampu memperbesar peluang benih berkecambah dengan baik dan dapat tumbuh menjadi bibit yang baik. Penelitian Susila et al. (2004) juga menyatakan bahwa penggunaan media rockwool secara umum memberikan hasil terbaik bagi pertumbuhan dan bobot panen selada pada sistem teknologi hidroponik sistem terapung (THST).

Proses pencelupan rockwool yang sebelumnya telah disusun benih di atasnya tidak efisien dan memiliki risiko yang sangat besar merusak susunan benih-benih. Benih-benih yang telah disusun dapat terlepas dan menempal di tempat yang lain. Hal ini dapat menghasilkan bibit yang tumbuh saling berhimpitan. Bibit tersebut sulit untuk dipisahkan, karena akar kedua bibit tersebut telah menyatu, sehingga jika dipisahkan akan merusak akar bibit. Person in charge (PIC) di perusahaan cenderung menanam dua bibit yang berhimpitan tersebut pada satu lubang tanam, tanpa memisahkannya. Hasil dari metode penanaman yang demikian akan mengakibatkan pertumbuhan tanaman yang berhimpitan tersebut kurang optimum, karena terbatasnya ruang bagi kedua tanaman tersebut untuk tumbuh. 
lubang $\begin{gathered}\text { Penanaman } \\ \text { tanam }\end{gathered}$ juga bibit dalam satu lubang tanam juga akan menyebabkan lubang tanam diisi satu bibit, menjadi satu lubang tanam diisi dua bibit. Masalah lain yang akan timbul dengan metode pencelupan seperti ini adalah dapat mengakibatkan jumlah benih yang ditanam berkurang akibat benih hanyut dalam air, akibatnya jumlah benih yang disemai juga berkurang yang pada akhirnya akan memperkecil jumlah bibit yang tumbuh di greenhouse nursery.

Perlakuan pengecambahan dilakukan di dalam ruang gelap dengan suhu berkisar antara $17{ }^{0} \mathrm{C}-25{ }^{0} \mathrm{C}$. Grubben et al. (1994) menyatakan bahwa benih selada akan berkecambah dalam kurun waktu empat hari, bahkan untuk benih yang viabel dapat berkecambah dalam waktu satu hari, pada suhu $15{ }^{0} \mathrm{C}-25{ }^{0} \mathrm{C}$. Berikut ini daya berkecambah benih disajikan pada Tabel 1 .

Tabel 1. Daya Berkecambah Benih Selada Keriting, Lollorossa dan Romaine

\begin{tabular}{lc}
\hline \multicolumn{1}{c}{ Komoditas } & Daya berkecambah (\%) \\
\hline Selada keriting & 77.50 \\
Lollorossa & 72.38 \\
Romaine & 85.31 \\
\hline
\end{tabular}

Daya berkecambah benih romaine dan selada keriting sudah baik, namun benih lollorossa memiliki daya berkecambah yang kurang baik, yaitu hanya sebesar $72.38 \%$. Menurut Sunarjono (2010) untuk penanaman selada di lapangan, daya berkecambah di atas $75 \%$ sudah dikatakan bagus.

\section{Produksi Sayuran}

Budi daya sayuran secara aeroponik menggunakan bak tanam fiberglass berukuran 4 $\mathrm{m} \times 1 \mathrm{~m}$ x $0.5 \mathrm{~m}$. Suplai larutan nutrisi disalurkan ke akar tanaman menggunakan pompa dengan daya listrik sebesar 800 - 1600 watt dengan debit $200-240$ L/menit melalui selang polyetilene dan disemprotkan melalui nozzle hijau dengan curah $0.83 \mathrm{~L} /$ menit. Tanaman ditopang dengan menggunakan styrofoam berukuran $1 \mathrm{~m} \mathrm{x}$ $1 \mathrm{~m}$, dengan lubang tanam sebanyak 49 lubang yang memiliki jarak antar lubang $14 \mathrm{~cm} \mathrm{x} 14 \mathrm{~cm}$. Budi daya sayuran secara hidroponik menggunakan bak tanam fiberglass berukuran $4 \mathrm{~m}$ x $1 \mathrm{~m}$ x $0.1 \mathrm{~m}$ dan juga bak tanam dari cor beton berukuran panjang yang disesuaikan dengan kondisi green house, dengan lebar bak $1 \mathrm{~m}$ dan kedalaman bak $0.1 \mathrm{~m}$. Sayuran yang ditaman dengan sistem hidroponik juga dipotong dengan menggunakan styrofoam dengan ukuran yang sama seperti pada budi daya secara aeroponik.

Budi daya secara aeroponik, khususnya selada keriting, sering dijumpai kondisi tinggi tanaman yang tidak merata. Apabila dilihat dari jauh, tinggi tanaman selada keriting tidak merata. Apabila dilihat dari jauh, tinggi tanaman selada keriting tidak seragam dan tampak seperti gelombang. Kondisi ini disebabkan oleh tidak meratanya semprotan nutrisi oleh nozzle dibawahnya. Nozzle yang digunakan merupakan nozzle yang memiliki arah semprotan ke dua arah yang saling berlawanan (seperti kerucut terbalik). Bentuk semprotan seperti ini menghasilkan suatu bagian yang tidak mendapatkan semprotan nutrisi, yaitu pada bagian tepat di atas nozzle. Bagian ini seharusnya masih bisa mendapat semprotan nutrisi yang berasal dari nozzle disebelahnya, namun pada kenyataannya, semprotan nozzle tidak mampu menyemprotkan nutrisi pada bagian tersebut dengan sempurna, sehingga bagian tersebut hanya mendapatkan sedikit semprotan nutrisi. Kondisi ini secara langsung dapat mengurangi produktivitas, dan keseragaman sebab tidak semua tanaman dalam satu bak menghasilkan ukuran yang besar secara seragam, melainkan ada beberapa yang kecil. Tanaman yang kecil tidak dapat dikemas dan dijual, sehingga akan mengurangi jumlah sayuran yang diproduksi. Upaya yang telah dilakukan untuk menanggulangi masalah ini adalah dengan mengganjal selang yang berada di dalam bak tanam dengan potongan styrofoam bekas, sehingga membuat kedudukan nozzle menjadi lebih tinggi. Dengan demikian, nozzle mampu saling mengisi bagian kosong seperti yang telah dijelaskan di atas.

\section{Pertumbuhan Selada Keriting}

Tinggi bibit tanaman selada keriting (0 HST) menunjukkan perbedaan, yaitu bibit selada keriting untuk budi daya aeroponik lebih tinggi dibandingkan bibit selada keriting yang digunakan untuk budi daya hidroponik (Tabel 2). Hasil Uji-T student menunjukkan bahwa tanaman selada keriting mulai dari 5 HST hingga 30 HST dan menunjukkan nilai yang berbeda tidak nyata. Hal ini menunjukkan bahwa kedua teknik budi daya mampu menghasilkan tinggi tanaman selada keriting yang sama.

Lebar daun selada keriting menunjukkan nilai yang tidak nyata pada 10 HST dan 15 HST, kemudian menunjukkan nilai yang nyata mulai dari 25 HST hingga 30. Perkembangan jumlah daun selada keriting menunjukkan nilai yang tidak berbeda nyata 
pada 0 HST sampai 15 HST kemudian menjadi nyata pada 20, 25 dan 30 HST. Jumlah daun selada keriting aeroponik pada saat panen (30 HST) sebanyak 10.10 helai, sedangkan jumlah daun selada keriting hidroponik sebanyak 7.50 helai (Tabel 2)

Tabel 2 menunjukkan nilai yang berbeda nyata antara panjang akar selada keriting aeroponik dan selada keriting hidroponik mulai dari 0 HST sampai 30 HST atau pada saat panen. Pertumbuhan akar selada keriting yang dibudi dayakan secara aeroponik lebih baik dibandingkan dengan selada keriting yang dibudi- dayakan secara hidroponik. Hal dikarenakan kondisi fisik akar selada keriting yang dibudidayakan secara aeroponik memiliki keadaan yang sehat, berwarna putih, panjang dan kuat, sedangkan penampakan akar selada keriting yang dibudidayakan secara hidroponik menunjukkan akar yang kurang sehat dengan cirri- ciri berwarna coklat, pendek dan rapuh. Menurut Resh (2004), akar yang sehat memiliki penampakan berwarna putih, tegar dan berserat banyak. Akar yang tidak sehat menunjukkan warna kecoklatan pada bagian ujung akar atau bagian akar.

Tabel 2. Pertumbuhan selada keriting

\begin{tabular}{|c|c|c|c|c|c|c|c|c|}
\hline \multirow{2}{*}{ Pengamatan } & \multirow{2}{*}{ T.B } & \multicolumn{7}{|c|}{ Umur selada keriting (HST) } \\
\hline & & 0 & 5 & 10 & 15 & 20 & 25 & 30 \\
\hline \multirow{2}{*}{$\begin{array}{l}\text { Tinggi } \\
\text { Tanaman }(\mathrm{cm})\end{array}$} & A & $7.49 \mathrm{a}$ & $8.16 \mathrm{a}$ & $8.62 \mathrm{a}$ & $12.49 \mathrm{a}$ & $16.74 a$ & $22.63 a$ & $26.27 \mathrm{a}$ \\
\hline & $\mathrm{H}$ & $5.92 \mathrm{~b}$ & $7.95 \mathrm{a}$ & $10.40 \mathrm{a}$ & $12.89 \mathrm{a}$ & $15.29 \mathrm{a}$ & $21.28 \mathrm{a}$ & $24.77 \mathrm{a}$ \\
\hline Lebar & $\mathrm{A}$ & $3.11 \mathrm{a}$ & $3.92 \mathrm{a}$ & $5.37 \mathrm{a}$ & $9.14 \mathrm{a}$ & $12.43 \mathrm{a}$ & $15.43 \mathrm{a}$ & $15.83 \mathrm{a}$ \\
\hline Daun (cm) & $\mathrm{H}$ & $2.34 \mathrm{~b}$ & $3.20 \mathrm{~b}$ & $5.67 \mathrm{a}$ & $8.51 \mathrm{a}$ & $10.88 b$ & $12.85 \mathrm{~b}$ & $14.19 \mathrm{~b}$ \\
\hline Jumlah & A & $3.00 \mathrm{a}$ & $3.50 \mathrm{a}$ & $4.10 \mathrm{a}$ & $5.20 \mathrm{a}$ & $6.90 \mathrm{a}$ & $9.40 \mathrm{a}$ & $10.10 \mathrm{a}$ \\
\hline Daun (helai) & $\mathrm{H}$ & $3.00 \mathrm{a}$ & $3.10 \mathrm{a}$ & $3.70 \mathrm{a}$ & $4.80 \mathrm{a}$ & $6.00 \mathrm{~b}$ & $7.20 \mathrm{~b}$ & $7.50 \mathrm{~b}$ \\
\hline Panjang & $\mathrm{A}$ & $2.18 \mathrm{a}$ & $6.75 \mathrm{a}$ & $12.15 \mathrm{a}$ & $19.44 \mathrm{a}$ & $27.29 \mathrm{a}$ & $36.91 \mathrm{a}$ & $37.57 \mathrm{a}$ \\
\hline Akar $(\mathrm{cm})$ & $\mathrm{H}$ & $0.80 \mathrm{~b}$ & $3.30 \mathrm{~b}$ & $6.31 \mathrm{~b}$ & $6.96 b$ & $6.83 b$ & $8.38 \mathrm{~b}$ & $7.68 \mathrm{~b}$ \\
\hline
\end{tabular}

Keterangan : T.B = teknik budi daya; $\mathrm{A}=$ aeroponik; $\mathrm{H}=$ hidroponik; Angka-angka pada yang sama yang diikuti oleh huruf yang sama menunjukkan tidak berbeda nyata berdasarkan uji-t pada taraf $5 \%$

Penyebab akar cokelat pada selada keriting hidroponik diduga lebih dikarenakan oleh kekurangan aerasi daripada akibat serangan penyakit seperti serangan Phytium sp. Infeksi cendawan ini pada akar dapat menyebabkan akar cokelat, juga menyebabkan tanaman menjadi kerdil Resh (2004). Hal ini tidak terjadi pada selada keriting hidroponik yang dapat dilihat dari pertumbuhan bagian tajuk tanaman yang masih aktif tumbuh. Hal ini sama seperti yang dinyatakan oleh Juliansyah (2010) dalam penelitiannya yang menyatakan bahwa akar cokelat pada tanaman bayam tidak mempengaruhi pertumbuhan dan produksi bayam.

Akar selada keriting hidroponik terendam dalam air sehingga diduga tidak mendapat cukup udara, yang pada akhirnya menyebabkan akar menjadi kecoklatan, seperti yang dinyatakan oleh Lakitan (1993) bahwa pada sistem perakaran yang tergenang biasanya akan terjadi proses fermentasi akibat oksigen yang tidak tersedia. Sistem budi daya hidropoik seperti ini menurut (Acquaah, 2009)

memang dapat menimbulkan masalah aerasi pada akar. Walaupun larutan nutrisi dipompa dan dialirkan kembali, namun kondisi akar tetap menunjukkan penampakan berwarna kecoklatan. Menurut Resh (2004) masalah aerasi pada budi daya secara hidroponik dapat diatasi dengan menggunakan pompa atau kompresor yang digunakan untuk membuat gelembunggelembung udara ke dalam bak tanam atau tangki nutrisi melalui pipa perforasi ataupun batu gelembung (airstoned).

Pertumbuhan tinggi tanaman lollorossa, pada 0 dan 5 HST menunjukkan pertumbuhan antara teknik budi daya aeroponik dan hidroponik berbeda nyata. Menginjak 10 HST sampai 30 HST, pertumbuhan tinggi tanaman pada kedua jenis budi daya tidak menunjukkan perbedaan yang nyata, walaupun menggunakan bibit yang tidak seragam. Pada saat panen, tinggi tanaman lollorossa.

Bibit yang digunakan pada penanaman lollorossa memiliki ukuran yang berbeda antara yang ditanam pada budi daya aeroponik dan yang ditanam pada budi daya hidroponik. Nilai keseragaman bibit lollorossa pada 0 HST menunjukkan nilai yang berbeda nyata, dimana bibit yang digunakan pada budi daya aeroponik memiliki lebar daun yang lebih lebar dibandingkan hidroponik. Lebar daun lollorossa pada kedua jenis teknik budi daya tidak menunjukkan perbedaan saat 5 HST sampai 20 HST. Perbedaan mulai terlihat saat tanaman menginjak umur 25 HST, dimana terjadi 
perbedaan yang nyata dengan rata-rata lebar daun lollorossa pada budi daya aeroponik sebesar 13.73 $\mathrm{cm}$ dan lebar daun lollorossa pada budi daya hidroponik sebesar $11.21 \mathrm{~cm}$. Pada usia 30 HST, lebar daun lollorossa pada kedua jenis teknik budi daya menunjukkan perbedaan yang nyata.

Jumlah daun bibit lollorossa yang ditanam pada 0 HST, baik pada sistem budi daya secara aeroponik maupun hidroponik menunjukkan angka yang hampir sama yaitu berkisar pada angka 3 helai daun. Pertumbuhan jumlah daun lollorossa yang dibudi dayakan secara aeroponik pada rentang waktu 10 HST sampai 15 HST menunjukkan angka yang lebih rendah daripada jumlah daun lollorossa yang dibudi dayakan secara hidroponik. Pada usia tanaman 20 HST, lollorossa yang ditanam dengan teknik budi daya aeroponik memiliki jumlah daun yang lebih banyak daripada jumlah daun lollorssa yang ditanam dengan teknik budi daya hidroponik, dan menjadi lebih banyak bila dibandingkan dengan lollorossa yang ditanam dengan sistem budi daya hidroponik. Pada saat panen, jumlah daun lollorossa yang ditanam dengan teknik aeroponik menunjukkan angka yang lebih tinggi daripada lollorossa yang ditanam dengan teknik budi daya hidroponik.

Tabel 3. Pertumbuhan lollorossa

\begin{tabular}{lllllllll}
\hline \multirow{2}{*}{ Pengamatan } & \multirow{2}{*}{ T.B } & \multicolumn{7}{c}{ Umur lorrorossa (HST) } \\
\cline { 3 - 8 } Tinggi & & 0 & 5 & 10 & 15 & 20 & 25 & 30 \\
Tanaman (cm) & $\mathrm{A}$ & $7.49 \mathrm{a}$ & $7.99 \mathrm{a}$ & $8.51 \mathrm{a}$ & $9.62 \mathrm{a}$ & $11.26 \mathrm{a}$ & $15.44 \mathrm{a}$ & $19.10 \mathrm{a}$ \\
Lebar & $\mathrm{H}$ & $4.33 \mathrm{~b}$ & $5.51 \mathrm{~b}$ & $7.66 \mathrm{a}$ & $9.55 \mathrm{a}$ & $11.11 \mathrm{a}$ & $13.79 \mathrm{a}$ & $17.71 \mathrm{a}$ \\
Daun (cm) & $\mathrm{A}$ & $4.32 \mathrm{a}$ & $4.41 \mathrm{a}$ & $5.26 \mathrm{a}$ & $7.31 \mathrm{a}$ & $9.81 \mathrm{a}$ & $13.73 \mathrm{a}$ & $15.35 \mathrm{a}$ \\
Jumlah & $\mathrm{H}$ & $2.72 \mathrm{~b}$ & $3.94 \mathrm{a}$ & $5.50 \mathrm{a}$ & $6.77 \mathrm{a}$ & $9.46 \mathrm{a}$ & $11.21 \mathrm{~b}$ & $13.02 \mathrm{~b}$ \\
Daun (helai) & $\mathrm{A}$ & $2.60 \mathrm{a}$ & $3.40 \mathrm{a}$ & $3.60 \mathrm{~b}$ & $4.30 \mathrm{~b}$ & $6.50 \mathrm{a}$ & $8.60 \mathrm{a}$ & $9.20 \mathrm{a}$ \\
Panjang & $\mathrm{H}$ & $3.00 \mathrm{a}$ & $3.10 \mathrm{a}$ & $4.20 \mathrm{a}$ & $5.20 \mathrm{a}$ & $5.70 \mathrm{~b}$ & $6.90 \mathrm{~b}$ & $8.50 \mathrm{~b}$ \\
Akar (cm) & $\mathrm{A}$ & $2.45 \mathrm{a}$ & $4.23 \mathrm{a}$ & $9.43 \mathrm{a}$ & $16.74 \mathrm{a}$ & $29.89 \mathrm{a}$ & $42.63 \mathrm{a}$ & $41.64 \mathrm{a}$ \\
\hline Keranga & $\mathrm{H}$ & $1.68 \mathrm{a}$ & $4.36 \mathrm{a}$ & $6.76 \mathrm{a}$ & $7.03 \mathrm{~b}$ & $6.87 \mathrm{~b}$ & $6.66 \mathrm{~b}$ & $7.37 \mathrm{~b}$ \\
\hline
\end{tabular}

Keterangan : T.B = teknik budi daya; $\mathrm{A}=$ aeroponik; $\mathrm{H}$ = hidroponik; Angka-angka pada yang sama yang diikuti oleh huruf yang sama menunjukkan tidak berbeda nyata berdasarkan uji-t pada taraf $5 \%$

Akar lollorossa yang ditanam pada kedua jenis teknik budi daya pada umur 5 HST dan 10 HST tidak menunjukkan perbedaan yang nyata. Panjang akar mulai menunjukkan perbedaan yang nyata pada 15 HST hingga panen yaitu pada 30 HST, panjang akar lollorossa pada teknik budi daya secara aeroponik memiliki nilai rata-rata $41.64 \mathrm{~cm}$, jauh lebih besar bila dibandingkan dengan akar lollorossa pada budi daya hidroponik yang rata-ratanya sebesar $7.37 \mathrm{~cm}$ (Tabel 3).

Sistem perakaran lollorossa yang dibudi dayakan dengan teknik budi daya secara aeroponik jauh lebih baik. Akarnya lebat, berwarna putih, panjang dan sehat seperti halnya akar pada selada keriting aeroponik. Hal tersebut karena budi daya secara aeroponik memiliki aerasi yang baik sehingga mampu tumbuh lebih optimal, sedangkan akar tanaman pada budi daya hidroponik berwarna coklat, pendek, dan rapuh pada ujung-ujung. Hal ini disebabkan oleh hal yang sama pada selada keriting.

\section{Pertumbuhan Romaine}

Tabel 4 menunjukkan bahwa mulai dari 0 HST sampai 25 HST, pertumbuhan tunggi tanaman romaine yang ditanam secara aeroponik maupun hidroponik menunjukkan angka yang berbeda nyata. Pertumbuhan tinggi tanaman yang dibudi dayakan secara hidroponik lebih baik daripada yang dibudi dayan secara aeroponik. Romaine yang menjadi tanaman sampel terpaksa dipanen pada usia 25 HST karena tanaman tersebut sudah mulai menunjukkan tanda-tanda diserang penyakit berupa blackspot. Supervisor panen mengambil tindakan dengan memanennya terlebih dahulu untuk mengurangi serangan yang lebih parah.

Jumlah daun bibit yang digunakan untuk menanam romaine berbeda antara yang ditanam dengan teknik budi daya aeroponik maupun yang ditanam dengan teknik hidroponik. Bibit yang ditanam pada budi daya hidroponik memilliki rata-rata jumlah daun yang lebih banyak. Pada 0 HST sampai $20 \mathrm{HST}$, jumlah daun romaine aeroponik lebih sedikit dibandingkan dengan romaine hidroponik. Pada usia tanaman 25 terlihat bahwa jumlah daun romaine aeroponik dan hidroponik saat panen adalah sama (Tabel 4).

Tabel 4 menunjukkan bahwa pada 0 dan 5 HST, panjang akar tidak menunjukkan perbedaan yang nyata antara budi daya aeroponik dan hidroponik. Perbedaan yang nyata mulai terlihat pada 15 HST sampai 25 HST, dengan rata-rata panjang akar romaine yang dibudi dayakan secara aeroponik sebesar $38.61 \mathrm{~cm}$, jauh diatas nilai 
panjang akar romaine yang dibudidayakan secara hidroponik yang rata-ratahanya sebesar $9.59 \mathrm{~cm}$. Kondisi akar romaine hidroponik juga menunjukkan penampakan yang sama seperti selada keriting dan lollorossa, yaitu berwarna coklat, pendek dan rapuh pada bagian ujungnya. hal tersebut didiga disebabkan oleh masalah aerasi.

Tabel 4. Pertumbuhan romaine

\begin{tabular}{llllllll}
\hline \multirow{2}{*}{ Pengamatan } & \multirow{2}{*}{ T.B } & \multicolumn{5}{c}{ Umur romaine (HST) } \\
\cline { 3 - 8 } & & 0 & 5 & 10 & 15 & 20 & 25 \\
\hline Tinggi & $\mathrm{A}$ & $6.04 \mathrm{~b}$ & $6.79 \mathrm{~b}$ & $8.15 \mathrm{~b}$ & $12.36 \mathrm{~b}$ & $16.39 \mathrm{~b}$ & $22.45 \mathrm{~b}$ \\
Tanaman (cm) & $\mathrm{H}$ & $8.15 \mathrm{a}$ & $11.24 \mathrm{a}$ & $14.38 \mathrm{a}$ & $16.96 \mathrm{a}$ & $20.86 \mathrm{a}$ & $24.51 \mathrm{a}$ \\
Lebar & $\mathrm{A}$ & $1.61 \mathrm{~b}$ & $2.24 \mathrm{~b}$ & $3.03 \mathrm{~b}$ & $5.54 \mathrm{~b}$ & $7.61 \mathrm{~b}$ & $9.99 \mathrm{a}$ \\
Daun (cm) & $\mathrm{H}$ & $2.31 \mathrm{a}$ & $3.46 \mathrm{a}$ & $5.31 \mathrm{a}$ & $7.17 \mathrm{a}$ & $9.49 \mathrm{a}$ & $10.02 \mathrm{a}$ \\
Jumlah & $\mathrm{A}$ & $2.10 \mathrm{~b}$ & $3.30 \mathrm{~b}$ & $3.60 \mathrm{~b}$ & $5.10 \mathrm{~b}$ & $8.20 \mathrm{a}$ & $10.10 \mathrm{a}$ \\
Daun (helai) & $\mathrm{H}$ & $3.60 \mathrm{a}$ & $4.10 \mathrm{a}$ & $5.80 \mathrm{a}$ & $7.40 \mathrm{a}$ & $8.60 \mathrm{a}$ & $10.20 \mathrm{a}$ \\
Panjang & $\mathrm{A}$ & $1.57 \mathrm{a}$ & $3.65 \mathrm{a}$ & $8.73 \mathrm{a}$ & $13.93 \mathrm{a}$ & $23.59 \mathrm{a}$ & $38.61 \mathrm{a}$ \\
Akar (cm) & $\mathrm{H}$ & $0.91 \mathrm{a}$ & $2.79 \mathrm{a}$ & $6.74 \mathrm{~b}$ & $6.72 \mathrm{~b}$ & $6.96 \mathrm{~b}$ & $9.59 \mathrm{~b}$ \\
\hline
\end{tabular}

Keterangan : T.B = teknik budi daya; $\mathrm{A}=$ aeroponik; $\mathrm{H}=$ hidroponik; Angka-angka pada yang sama yang diikuti oleh huruf yang sama menunjukkan tidak berbeda nyata berdasarkan uji-t pada taraf $5 \%$

\section{Aspek Panen dan Pasca Panen}

Bobot Panen. Bobot selada keriting dan romaine menunjukkan perbedaan yang nyata, dimana yaitu bobot selada keriting dan romaine menunjukkan nilai yang lebih baik. Hal ini disebabkan karena lebar daun, jumlah daun dan juga panjang akar selada keriting menunjukkan perbedaan yang cukup signifikan.

Selada keriting yang dibudi dayakan secara aeroponik memberikan hasil yang lebih baik dibandingkan selada keriting yang dibudi dayakan secara hidroponik, akan tetapi berdasarkan dari semua parameter yang diamati perbedaan yang paling signifikan tampak pada panjang akar. Panjang akar selada keriting aeroponik memiliki nilai hampir lima kali lipat lebih besar dibandingkan panjang akar selada keriting hidroponik. Hal tersebut diduga memberikan kontribusi yang besar dalam perbedaan bobot panen selada keriting. Hal yang sama diduga terjadi pada romaine, panjang akar romaine aeroponik lebih panjang emapt kali lipat daripada akar romaine hidroponik memiliki kontribusi yang besar terhadap perbedaan bobot panen yang besar antara romaine aeroponik dan romaine hidroponik.

Produktivitas. Analisis pertumbuhan selada keriting, lollorossa dan romaine menunjukkan kecenderungan bahwa budi daya secara aeroponik dapat memberikan hasil panen yang lebih baik. Hal ini juga dapat dilihat pada data produktivitas yang dimiliki (data sekunder) pada bulan Maret-Mei 2011. Selada keriting, lollorossa dan romaine yang dibudi dayakan secara aeroponik memang mampu memberikan hasil yang lebih baik jika dibandingkan dengan sayuran yang dibudi dayakan secara hidroponik.

Tabel 5. Bobot panen selada, lollarossa dan romaine

\begin{tabular}{clcc}
\hline \multirow{2}{*}{$\begin{array}{c}\text { Teknik } \\
\text { Budi daya }\end{array}$} & \multicolumn{3}{c}{ Bobot per tanaman saat panen $(\mathrm{g})$} \\
\cline { 2 - 4 } & $\begin{array}{l}\text { Selada } \\
\text { kering }\end{array}$ & Lollarossa & Romaine \\
\hline Aeroponik & $89.00 \mathrm{a}$ & $42.00 \mathrm{a}$ & $93.00 \mathrm{a}$ \\
Hidroponik & $53.00 \mathrm{~b}$ & $53.00 \mathrm{~b}$ & $59.00 \mathrm{~b}$ \\
\hline Keterangan : Nilai pada baris yang sama yang diikuti oleh \\
huruf yang sama menunjukkan tidak berbeda \\
nyata berdasarkan uji-t taraf 5\%
\end{tabular}

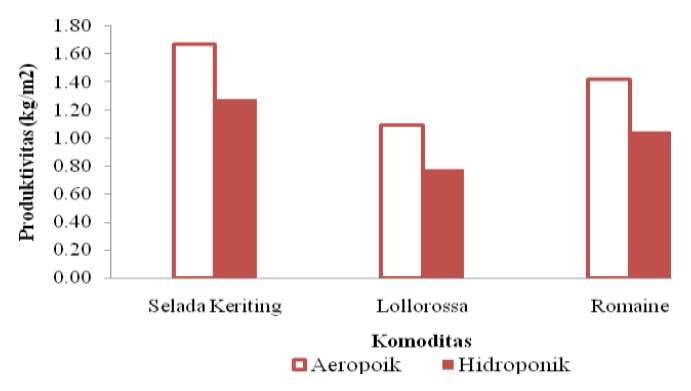

Gambar 1. Produktivitas selada keriting, lollorossa, dan romaine periode Maret-Mei 2011 
Tanaman yang Tidak Dipanen. Panen yang dilakukan pada pagi yaitu pada pukul 06.30 WIB dan sore hari pada pukul 16.00 merupakan pemilihan waktu yang tepat, sebab menurut Haguluha (2007) waktu panen yang baik adalah pada waktu terdingin pada suatu hari, yaitu pada awal pagi ataupun pada sore hari jika ingin memanen sayuran yang akan dikirim ke daerah lain sehingga meminimalisir kerusakan hasil panen akibat transpirasi.

Pada Tabel 6, dapat dilihat bahwa presentase tanaman yang tidak dipanen pada tanaman selada kerititng aeroponik maupun hidroponik menunjukkan angka yang kecil. Hal ini menunjukkan bahwa baik budi daya yang dilakukan secara aeroponik maupun hidroponik mampu menghasilkan tanaman selada keriting yang baik, karena kurang lebih 95\% tanaman dapat dipanen.

Tanaman lollorossa juga menunjukkan hal yang sama. Pada Tabel 6, presentase tanaman lollorossa aeroponik yang tidak dipanen sebesar $5.90 \%$ dan sebesar $4.99 \%$ pada budi daya secara hidroponik. Angka tersebut tidak menunjukkan perbedaan yang nyata, sehingga dapat disimpulkan bahwa tanaman lollorossa yang dibudi dayakan secara aeroponik maupun hidroponik dapat menghasilkan hasil panen yang sama.

Persentase tanaman romaine yang tidak dipanen pada budi daya secara aeroponik sebesar
$6.22 \%$, sedangkan yang dibudidayakan secara hidroponik sebesar $7.50 \%$. Walaupun presentasenya sedikit lebih tinggi daripada selada keriting dan lollorossa, hasil panen romaine masih dianggap baik, sebab presentase tanaman yang dapat dipanen masih di atas $90 \%$.

Tabel 6. Persentase tanaman yang tidak dipanen

\begin{tabular}{|c|c|c|}
\hline Tanaman & Aeroponik & Hidroponik \\
\hline & \multicolumn{2}{|c|}{ 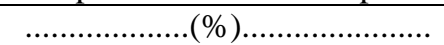 } \\
\hline Selada kering & $5.01 \mathrm{a}$ & $3.98 \mathrm{a}$ \\
\hline Lollorossa & $5.90 \mathrm{a}$ & $4.99 a$ \\
\hline Romaine & $6.22 \mathrm{a}$ & $7.50 \mathrm{a}$ \\
\hline Keterangan: N & $\begin{array}{l}\text { baris ya } \\
\text { sama markan uj }\end{array}$ & $\begin{array}{l}\text { ang diikuti } 0 \\
\text { an tidak berb } \\
\text { raf } 5 \%\end{array}$ \\
\hline
\end{tabular}

Kehilangan hasil . Selada keriting menunjukkan hasil berbeda pada tanaman yang mengalami sortasi baik pada tanaman yang dibudi dayakan secara aeroponik maupun hidroponik. Lollorossa menunjukkan hasil analisis perlakuan pasca panen yang sama seperti hasil yang ditunjukkan oleh selada keriting, sehingga tanaman yang dihasilkan dari kedua teknik budi daya tersebut baik. Romaine yang dibudidayakan secara aeroponik menunjukkan angka yang lebih kecil, yaitu sebesar $2.65 \%$, sehingga romaine yang dibudi dayakan secara aeroponik dapat menghasilkan kualitas tanaman lebih baik dibandingkan hidroponik (Tabel 7).

Tabel 7. Kehilangan hasi saat perlakuan pascapanen

\begin{tabular}{|c|c|c|c|c|}
\hline \multirow{2}{*}{ Komoditas } & \multirow{2}{*}{ T.B } & Sortasi & Rompesan daun & Kehilangan hasil \\
\hline & & \multicolumn{2}{|r|}{$(\%) \ldots \ldots \ldots \ldots \ldots \ldots$} & \\
\hline \multirow{2}{*}{ Selada keriting } & $\mathrm{A}$ & $6.40 \mathrm{a}$ & $24.09 \mathrm{a}$ & $30.50 \mathrm{a}$ \\
\hline & $\mathrm{H}$ & $1.94 \mathrm{a}$ & $24.01 \mathrm{a}$ & $25.96 a$ \\
\hline \multirow{2}{*}{ Lollorossa } & $\mathrm{A}$ & $6.25 \mathrm{a}$ & $15.71 \mathrm{a}$ & $21.96 \mathrm{a}$ \\
\hline & $\mathrm{H}$ & $6.60 \mathrm{a}$ & $19.83 \mathrm{a}$ & $26.40 \mathrm{a}$ \\
\hline \multirow{2}{*}{ Romaine } & $\mathrm{A}$ & $2.65 a$ & $27.05 \mathrm{a}$ & $29.70 b$ \\
\hline & $\mathrm{H}$ & $7.82 b$ & $27.34 \mathrm{a}$ & $35.16 \mathrm{a}$ \\
\hline
\end{tabular}

Keterangan: - T.B= Teknik Budi daya; $\mathrm{A}=$ Aeroponik; $\mathrm{H}=$ Hidroponik -Nilai pada kolom pada pengamatan yang sama yang diikuti oleh huruf yang sama menunjukkan tidak berbeda nyata berdasarkan uji $\mathrm{T}$ pada taraf $5 \%$

Hasil analisis data menunjukkan bahwa rompesan daun yang dilakukan terhadap tanaman yang dibudidayakan secara aeroponik dan hidroponik tidak berbeda nyata pada semua komoditas. Rompesan daun pada selada keriting berkisar pada angka 24\%, sedangkan pada romaine $27 \%$. Lollorossa yang dibudidayakan secara hidroponik menunjukkan angka yang lebih besar yaitu sebesar $19.83 \%$ daripada lollorossa yang dibudi dayakan secara seroponik yaitu sebesar $15.71 \%$.

Kehilangan hasil selada keriting akibat sortasi dan rompesan daun pada teknik budi daya aeroponik maupun hidroponik tidak menunjukkan perbedaan yang nyata, yaitu sebesar $30.50 \%$ pada selada keriting aeroponik, dan $25.96 \%$ pada selada keriting hidroponik. Lollorossa juga menunjukkan hasil analisis data yang tidak berbeda nyata, dengan rata-rata kehilangan hasil sebesar $21.96 \%$ pada lollorossa aeroponik dan $26.40 \%$ pada lollorossa hidroponik. Hasil yang berbeda ditunjukkan oleh romaine dimana hasil analisis data menunjukkan bahwa kehilangan hasil antara romaine aeroponik dan hidroponik menunjukkan nilai yang berbeda nyata. Kehilangan hasil romaine aeroponik sebesar 
$29.70 \%$, lebih baik jika dibandingkan dengan romaine hidroponik yang menunjukkan rata-rata kehilangan hasil sebesar 35.16\%.

Faktor-faktor penyebab dilakukannya perompesan daun diantaranya karena tiga hal berikut ini, yaitu perlakuan perompesan daun akibat daun rusak diserang hama, perompesan daun akibat penyakit, dan perompesan daun yang dilakukan terhadap daun tua atau kerusakan mekanis. Perompesan dilakukan dengan cara membuang daun terluar seperti yang dinyatakan oleh Haguluha et al. (2007) bahwa perlakuan perompesan daun dilakukan terhadap daun yang kering (berwarna cokelat) yang terdapat pada bagian dasar atau bagian paling luar termasuk daun yang rusak atau memar juga harus dibuang.

Tabel 8. Perlakuan perompesan daun

\begin{tabular}{ccrcc}
\hline \multirow{2}{*}{ Komoditas } & T.B & Hama & Penyakit & Duan tua/mekanis \\
\cline { 2 - 5 } Selada keriting & $\mathrm{A}$ & $0.89 \mathrm{a}$ & $\ldots \ldots \ldots \ldots \ldots \ldots \ldots \ldots \ldots \ldots \ldots \ldots \ldots \ldots \ldots \ldots \ldots \ldots \ldots$ & \\
& $\mathrm{H}$ & $0.57 \mathrm{a}$ & $1.43 \mathrm{~b}$ & $97.68 \mathrm{a}$ \\
\multirow{2}{*}{ Lollorossa } & $\mathrm{A}$ & $10.34 \mathrm{a}$ & $22.53 \mathrm{a}$ & $76.90 \mathrm{~b}$ \\
\multirow{2}{*}{ Romaine } & $\mathrm{H}$ & $0.57 \mathrm{a}$ & $27.59 \mathrm{a}$ & $62.07 \mathrm{a}$ \\
& $\mathrm{A}$ & $3.13 \mathrm{a}$ & $22.53 \mathrm{a}$ & $76.90 \mathrm{a}$ \\
& $\mathrm{H}$ & $5.00 \mathrm{a}$ & $29.39 \mathrm{a}$ & $67.48 \mathrm{a}$ \\
\hline
\end{tabular}

Keterangan: T.B= Teknik Budi daya; $\mathrm{A}=$ Aeroponik; $\mathrm{H}=$ Hidroponik -Nilai pada kolom pada pengamatan yang sama yang diikuti oleh huruf yang sama menunjukkan tidak berbeda nyata berdasarkan uji $\mathrm{T}$ pada taraf $5 \%$

\section{Analisis Usaha Tani}

Selada Aeroponik. Asumsi budi daya selada aeroponik yang diusahakan, berada pada lahan seluas $4000 \mathrm{~m}^{2}$ dengan menggunakan greenhouse tipe bulbo dengan bahan dasar alumunium dengan luas greenhouse $2000 \mathrm{~m}^{2}$. Asumsi ini berdasarkan pada luas greenhouse C yang terdapat di Kebun Cikahuripan 1 yang memiliki luas sekitar $2000 \mathrm{~m}^{2}$. Greenhouse C diambil sebagai contoh, sebab greenhouse ini mampu menghasilkan selada keriting dengan produktivitas yang paling tinggi diantara greenhouse lainnya, yaitu sebesar $1.77 \mathrm{~kg} \mathrm{~m}^{-2}$.

Usaha budi daya selada keriting ini akan membutuhkan biaya investasi sebesar Rp 1152 760000 dan biaya operasional per tahun sebesar Rp 303179 000. Biaya yang dikeluarkan cukup mahal, namun biaya ini sebanding dengan pemasukan yang akan didapatkan, dimana pemasukan setiap tahun dari penjualan selada aeroponik mencapai Rp 730080000 per tahun. Angka tersebut berdasarkan asumsi dalam satu bulan, kegiatan panen dilakukan sebanyak 26 kali dengan jumlah bak yang dipanen setiap harinya sebanyak 10 bak tanam $\left(40 \mathrm{~m}^{2}\right)$ dan dengan produktivitas sebesar $1 \mathrm{~kg} \mathrm{~m}^{-2}$.

Kegiatan panen sebanyak 26 kali dihitung berdasarkan kegiatan panen yang dilakukan, yaitu sebanyak kurang lebih 26 kali dalam satu bulan. Jumlah bak yang dipanen sebanyak 10 bak per hari berdasarkan perhitungan jumlah total bak tanam yaitu sebanyak 260 bak tanam dibagi dengan jumlah hari panen per bulannya yaitu sebanyak 26 kali, sehingga didapatkan hasil sebesar 10 bak tanam yang dipanen setiap harinya.

Perhitungan jumlah total bak tanam sebanyak 260 buah berdasarkan diskusi yang dilakukan oleh penulis dengan karyawan yang menyatakan bahwa dalam budi daya aeroponik dan hidroponik, pengaturan jumlah bak tanam lebih berdasarkan pada optimalisasi kekuatan semprotan pompa daripada optimalisasi lahan. Hal ini dapat dilihat pada data rata-rata luas produktif dibandingkan dengan luas greenhouse sebesar $57.21 \%$.

Net B/C adalah manfaat bersih yang menguntungkan terhadap bisnis yang dihasilkan setiap satu satuan kerugian dari bisnis tersebut (Nurmalina et al., 2009). Dengan kata lain, net $\mathrm{B} / \mathrm{C}$ adalah manfaat bersih yang diterima oleh suatu perusahaan untuk setiap satu satuan biaya yang dikeluarkan untuk suatu usaha. Suatu usaha dikatakan layak apabila memiliki nilai net $\mathrm{B} / \mathrm{C}$ lebih besar dari 1.00. Net $\mathrm{B} / \mathrm{C}$ dari usaha ini mencapai 2.48, sehingga dapat dikatakan layak karena memenuhi syarat net $\mathrm{B} / \mathrm{C}$ lebih besar dari 1.00. IRR (Internal Rate of Return) adalah tingkat pengembalian yang dapat diberikan oleh suatu usaha yang dijalankan, yang berasal dari investasi yang digunakan. IRR dinyatakan dalam persen. Suatu usaha dapat dikatakan layak apabila nilai IRR lebih besar dari faktor diskonto yang berlaku. IRR yang dimiliki usaha budi daya selada aeroponik menunjukkan nilai yang baik, yaitu sebesar $32.64 \%$, jauh lebih besar dari faktor diskonto yang berlaku yaitu $17 \%$. Periode pengembalian (payback periode) adalah waktu yang dibutuhkan untung mengembalikan lagi 
uang investasi. Periode pengembalian untuk budi daya selada aeroponik adalah selama 4 tahun.

Selada Hidroponik (DFT). Budi daya selada hidroponik menggunakan sistem DFT dengan menggunakan asumsi luas lahan dan luas greenhouse yang sama dengan budi daya selada aeroponik membutuhkan biaya investasi sebesar Rp 916760 000. Pemasukan per tahun yang didapatkan dari penjualan selada adalah sebesar Rp 584064 000. Nilai tersebut lebih kecil bila dibandingkan dengan pemasukan selada aeroponik. Hal ini disebabkan oleh produktivitas selada hidroponik yang lebih kecil, yang mana produktivitas maksimal hanya mencapai $1.30 \mathrm{~kg}$ $\mathrm{m}^{-2}$. Net B/C yang diperoleh dari usaha budi daya selada hidroponik adalah 1.85 dengan IRR $19.6 \%$. periode pengembalian lebih lama daripada usaha budi daya selada aeroponik, yaitu selama 5.3 tahun.

Apabila dibandingkan anatara biaya investasi yang dikeluarkan dan juga pendapatan yang diterima, maka usaha budi daya selada secara aeroponik lebih menjajikan dibandingkan usaha budi daya selada secara hidroponik. Walaupun biaya investasi dan operasional per tahunnya mahal, analisis usaha tani budi daya selada keriting aeroponik menunjukkan nilai Net $\mathrm{B} / \mathrm{C}$, IRR dan juga payback period yang lebih baik dibandingkan usaha budi daya hidroponik (DFT).

\section{KESIMPULAN}

Dilihat dari cara budi dayanya, budi daya sayuran dengan teknik budi daya aeroponik maupun hidroponik memiliki banyak persamaan. Persamaannya dapat dilihat mulai dari kegiatan persemaian, penanaman, panen dan juga pasca panen. Perbedaan budi daya secara aeroponik dan hidroponik terletak pada kegiatan perawatan yaitu pada perawatan nozzle. Perbedaan yang lain terletak pada pertumbuhan tanaman dan juga dari segi analisis usaha tani. Hasil pengamatan pertumbuhan menunjukkan bahwa pertumbuhan selada keriting, lollorossa dan romaine menunjukkan hasil yang lebih baik pada budi daya aeroponik. Pada aspek pasca panen selada keriting, lollorossa dan romaine, baik yang ditanam secara aeroponik maupun hidroponik, secara umum tidak menunjukkan perbedaan yang nyata. Kehilangan hasil akibat pasca panen cukup tinggi, dan kebanyakan berasal dari perompesan daun akibat daun tua atau kerusakan mekanis, dibandingkan dengan kerusakan akibat hama dan penyakit. Analisis usaha tani menunjukkan bahwa angka investasi untuk budi daya selada aeroponik lebih mahal bila dibandingkan dengan usaha budi daya selada hidroponik, namun usaha budi daya aeroponik lebih layak dan menguntungkan jika dijalankan.

\section{DAFTAR PUSTAKA}

Acquaah, G. 2009. Horticulture: Principles and Practices. Fourth Edition. Ohio: Pearson Prentice Hall.

Grubben, G.J.H., S. Sukprakarn. 1994. Lactuca sativa L. In: Siemonsma, J. S., Pileuk, K., Eds. PROSEA (Plant Resources in South east Asia 8): Vegetables. Prosea Foundation, Bogor. p 186-190.

Haguluha, V., Natera, E. 2007. Quality Management of Fresh Produce from The Highlands of Papua New Guinea. Australian Center for International Agricultural Research.

Juliansyah, D. 2010. Pengaturan pemberian nutrisi untuk mengatasi akar cokelat tanaman bayam yang dibudidayakan secara aeroponik [skripsi]. Bogor (ID): Institut Pertanian Bogor.

Kementrian Perdagangan Republik Indonesia. 2011. Ekspor Non-migas Utama [Internet]. [diunduh $2011 \mathrm{Feb}$ 2]. Tersedia pada: http://www.kemendag.go.id.

Lakitan, B. 1993. Dasar-Dasar Fisiologi Tumbuhan. Jakarta (ID): Rajawali Pers.

Lingga, P. 1999. Hidoponik: Bercocok Tanam Tanpa Tanah. Jakarta (ID): Penebar Swadaya.

Nurmalina, R., Sarianti, T., Karryadi, A. 2009. Studi Kelayakan Bisnis. Bogor (ID): Departemen Agribisnis, Fakultas Ekonomi dan Manajemen, IPB.

Resh, H.M. 2004. Hydroponic Food Production. New Jersey (ID): New Concept Press.

Rubatzky, V.E., Yamaguchi, M. 1999. World Vegetables: Principles, production, and nutritive values. Second Edition. Maryland: Aspen Publishers, Inc.

Sunarjono, H. 2010. Bertanam 30 Jenis Sayur. Jakarta (ID): Penebar Swadaya. 
Susila, A.D., Koerniawati, Y. 2004. Pengaruh volume dan jenis media tanam pada pertumbuhan dan hasil tanaman selada (Lactuca sativa) dalam teknologi hidroponik sistem terapung. Bul Agron. 32(3): 16-21.
Sutiyoso, Y. 2003. Aeroponik Sayuran: Budi daya dengan Sistem Pengabutan. Jakarta (ID): Penebar Swadaya.

Untung, O. 2004. Hidroponik Sayuran Sistem NFT (Nutrient Film Technique). Jakarta (ID): Penebar Swadaya. 